\title{
EFFECT OF COLOUR OF PLASTIC NET HOUSE COVER AND SOIL MULCH ON GROWTH AND PRODUCTIVITY OF CUCUMBER
}

\author{
SALEH, S. M. ${ }^{1}$ AND S. M. K. ABOU-SHLEEL ${ }^{2}$ \\ Central Laboratory for Agricultural Climate, ARC, Dokki, Giza, Egypt. \\ Dept. of Environment and Bio-Agric., Fac. of Agric., Al-Azhar Univ., Cairo, Egypt.
}

(Manuscript received 2011)

\begin{abstract}
The current study was conducted at El-Nubaria area, ElBehera Governorate, Egypt, during autumn 2009 and 2010 seasons in order to investigate the growth and productivity of cucumber (Cucumis sativus L. C.v. Hesham $F_{1}$ hybrid) under different plastic net cover colours and different plastic mulch colours. Seeds were sown on first of September and seedlings were transplanted in $15^{\text {th }}$ of September 2009 \& 2010, respectively.

Three plastic net colours were applied, namely, red, blue and white whereas the white was used as a control. In addition two-soil plastic mulch colours (black and transparent) were applied for each house, besides bare soil (without mulching) as control.

The best results were obtained under the white plastic net (control), which had the highest total yield as well as light intensity, followed by the red, and finally blue plastic net colour. The highest length of plant, total leaf area and number of leaves as well as air temperature and humidity, soil temperature, were found in the red plastic net colour, followed by control and finally with the blue plastic net cover colour. Results also indicated that the white plastic mulch was recorded the highest values of all measured parameters followed by black and without mulching. Interaction between plastic net colours and plastic mulch showed that, the white net with transparent plastic mulch treatment had the highest plant, yield and soil temperature, but the treatment of transparent plastic mulch under red net colour had the highest number of leaves, leaf area and stem diameter.
\end{abstract}

Key words: Microclimate - Plastic net colour - Soil plastic mulchNet houses.

\section{INTRODUCTION}

Cucumber is one of the major vegetable crops grown in Egypt under plastic house conditions. It is sub-tropical vegetable crop that grows successfully under conditions of high light, humidity, moisture, temperature and fertilizers inside plastic houses (El-Aidy, 1990).

Plastic greenhouses business has a strong influence on the horticultural industry in many countries. Among the plastic sheets more attention is given to different kinds of polyethylene films, because they have low cost and can be manufactured in a wide range of thickness, width, colour and quality. 
Researches to improve the quality of different kinds of greenhouse covers are conducted to improve the plastic films with better light and heat transmission characteristics (Hanras, 1970). Many scientists hypothesized that photosynthetic rate of plants would generally fallow the intercepted light of the primary photosynthetic pigments. Results indicated that under blue and red light photosynthesis theorized the most often the group under white light followed by blue, green, orange, yellow, violet, purple and green then ultraviolet replicates. Effects of Phytochromes unrelated to photosynthesis may have significantly benefited or been detrimental to the health of plants under certain wavelengths replicates.

Plastic mulches offer many advantages to growers, including earlier and higher overall yields, reduced evaporation, fewer weed problems, reduced fertilizer leaching, reduced soil compaction, elimination of root pruning, cleaner produce, more effective fumigation and the ability to double the crop (Halil and Demirtas, 2006). Different types of mulch affect the vegetative growth and yield of cucumber plants, whereas different mulch colours and types affects soil temperatures and lead to favorite effect on the growth and yield of cucumber plants. The influence of the type of polyethylene mulch on soil temperature and crop response was dependent upon film colour (Lippert and Witing, 1964). Black polyethylene exchanged large quantities of energy with the atmosphere and caused relatively small changes in soil temperature, while transparent polyethylene film transmitted radiation to the soil surface which was absorbed and converted to sensible heat and plastic mulching increased total yield (salman and Gorski, 1985).

This study was done to investigate the colour of plastic net house and soil mulch on growth and productivity of cucumber (Cucumis sativus L. c.v. Hesham $F_{1}$ hybrid) under red and blue plastic net in comparison with normal plastic net colour and to determine the effects of mulch colour on cucumber growth and yield under net houses colours.

\section{MATERIALS AND METHODS}

The study has been established at El-Nubaria area, El-Behera Governorate, Egypt, to evaluate different Net plastic colour as a Net house cover, on the growth and production of cucumber (Cucumis sativus L. c.v. Hesham $F_{1}$ hybrid). Soil in ElNubaria area is sandy loam. Seeds were sown on first of September 2009 \& 2010 and seedlings were transplanted on $15^{\text {th }}$ September $2009 \& 2010$, respectively, in plastic Net houses of $540 \mathrm{~m}^{2}$ (Net house dimensions were $9 \mathrm{~m}$ wide, 60 length and $3.2 \mathrm{~m}$ height). Distances between Net houses were $2 \mathrm{~m}$. Net houses have been covered by 
three plastic colours; red and blue in comparison with white colour (control). In addition two-soil mulch plastic colour (black and transparent) was applied in each house, besides bare soil (without mulch) as control. Drip irrigation system was installed. Plants were irrigated two or three times daily depending on potential evapotranspiration using drippers of 4 liter/hr capacity. Soil has been prepared and the following amounts of fertilizers were added per Net house: three cubic meters of decomposed manure, $35 \mathrm{~kg}$ ammonium nitrate, $50 \mathrm{~kg}$ potassium sulfate, $100 \mathrm{~kg}$ super phosphate calcium and10 $\mathrm{kg}$ magnesium sulfate. The fertilizers with all treatments were applied to plants in form of nutrient solution. All required macro and micro nutrients for cucumber growth were added to the nutrient solution.

\section{Measurements}

\section{Microclimate Parameters}

\section{Light intensity}

Light intensity was measured in each net house daily at mid-day by portable Lux-meter (Model FMC- 10M).

\section{Air temperature and relative humidity}

Estimating maximum, minimum, and average air temperature and relative humidity were measured using a digital Thermo-hygrometer (model Art. No. 305000/30-5002) in the middle part of each of the three net houses. The digital Thermo-hygrometer was calibrated every four days against mercury thermometer and a reference hygrometer before the start of each season

\section{Soil temperature}

Soil temperature was measured daily at mid-day by using a soil thermometer at $20 \mathrm{~cm}$ depth and was recorded daily at mid-day.

Plant growth Parameters: Plant height from cotyledonary node to the terminal bud was measured, data was recorded after 20, 40, 60 and 80 days from transplanting. Number of leaves was measured after 20,40, 60 and 80 days from transplanting date. Stem diameter was measured after 20, 40, 60 and 80 days from transplanting date. Total leaf area for all leaves of the plant was measured after 80 days from transplanting date, by using a digital portable leaf area meter (LI-300 area meter produced by LI-COR, Lincoln, Nebraska, USA). Total fruit weight was calculated as a summation of all the fruit pickings per plant during the season (from beginning and ending of harvest period).

\section{Statistical analysis}

The collected data were subjected to the proper statistical analysis of complete randomized block design combined over locations according to Steel and Torrie (1980) using LSD at $5 \%$ level. 


\section{RESULTS AND DISCUSSION}

\section{Microclimate parameters}

\section{Light intensity}

Light intensity at noon under different net plastic house colour treatments revealed that there were significant differences among the treatments through 2009 and 2010 seasons. However, light intensity under the control treatment (white colour) was higher than red followed by the blue colour. The light intensity was decreased by $34 \%$ when blue net plastic was employed compared to the white plastic net (control). Meanwhile, the reduction of light intensity reached $12 \%$ only in case of using the red plastic net compared to the control. Data of the second season had the same trend as the first season (Table 1). These results were confirmed with that indicated by (Mortensen and Stromme, 1987) who mentioned that light penetrates transparent glass or plastic, and the spectral distribution of light will differ with the colour of the transparent material

Plastic cover reduced total light intensity and different-density shade clothes. Within certain range, the one percent reduction in radiation on the crop canopy is worth one percent reduction in yield (Hanan, 1990).

Any loss of light at levels less than saturation results in a decrease in productivity. A linear relationship has been reported between the reduction in cumulative light and the decrease in final yield (Cockshull, 1988).

Table 1. A average of light intensity (Lux) at noon under different plastic net colour treatments during the two growing seasons of 2009 and 2010.

\begin{tabular}{|c|c|c|c|}
\hline \multirow{2}{*}{$\begin{array}{c}\text { Days after } \\
\text { Transplanting }\end{array}$} & Red & Blue & Control \\
\cline { 2 - 4 } & \multicolumn{4}{|c|}{ First season } \\
\hline $\mathbf{3 0}$ & 27800.0 & 22100.0 & 28300.0 \\
\hline $\mathbf{6 0}$ & 24220.0 & 17900.0 & 26300.0 \\
\hline $\mathbf{9 0}$ & 12150.0 & 9100.0 & 15750.0 \\
\hline Mean & $\mathbf{2 1 3 9 0 . 0}$ & $\mathbf{1 6 6 6 6 . 7}$ & $\mathbf{2 3 4 5 0 . 0}$ \\
\hline & $\mathbf{S e c o n d ~ s e a s o n}$ & \\
\hline $\mathbf{3 0}$ & 33160.0 & 26320.0 & 33760.0 \\
\hline $\mathbf{6 0}$ & 28864.0 & 21280.0 & 31360.0 \\
\hline $\mathbf{9 0}$ & 14380.0 & 11800.0 & 18700.0 \\
\hline Mean & $\mathbf{2 3 7 7 0 . 0}$ & $\mathbf{1 9 8 0 0 . 0}$ & $\mathbf{2 7 9 4 0 . 0}$ \\
\hline
\end{tabular}




\section{Air temperature}

In the first season, maximum air temperature exposed to blue plastic net decreased by $1^{\circ} \mathrm{C}$, while the minimum air temperature decreased in average by $0.95^{\circ} \mathrm{C}$; meanwhile data indicate that air maximum and minimum temperatures were increased in case of using red plastic net by $1.35^{\circ} \mathrm{C}$, and $1.15^{\circ} \mathrm{C}$ respectively. The same trend of maximum and minimum temperature under different types of plastic net colours was obtained in the second season (Table 2).

On the other hand, data in Table 1 illustrated that blue plastic gave the lowest light intensity, lowest maximum and lowest minimum temperatures, followed by red colour compared to control. These results agree with Medany et. al.., (1991) who demonstrated that transmission of rays affected the heat requirement of plastic house, and the development of the plant, also pepper growth and production were increased when higher heat requirements were used. Higher light transmission increased heat gain under plastic house, and consequently improved maximum and minimum temperatures.

Table 2. Average of maximum and minimum air temperature under different plastic net colour treatments during the two growing seasons of 2009 and 2010.

\begin{tabular}{|c|c|c|c|c|c|c|}
\hline \multirow{2}{*}{$\begin{array}{c}\text { Days after } \\
\text { transplanting }\end{array}$} & \multicolumn{7}{|c|}{ Red } & \multicolumn{2}{c|}{ Blue } & \multicolumn{2}{c|}{ Control } \\
\cline { 2 - 7 } & Max. & Min. & Max. & Min. & Max. & Min. \\
\cline { 2 - 7 } & \multicolumn{7}{|c|}{ First season } & 18.7 \\
\hline $\mathbf{3 0}$ & 40.5 & 19.4 & 38.8 & 17.5 & 39.9 & 15.5 \\
\hline $\mathbf{6 0}$ & 36.8 & 16.9 & 34.5 & 14.5 & 35.0 & 12.7 \\
\hline $\mathbf{9 0}$ & 28.5 & 11.4 & 26.9 & 11.4 & 27.5 & $\mathbf{1 5 . 6}$ \\
\hline Mean & $\mathbf{3 5 . 3}$ & $\mathbf{1 5 . 9}$ & $\mathbf{3 3 . 4}$ & $\mathbf{1 4 . 5}$ & $\mathbf{3 4 . 1}$ & \\
\hline \multicolumn{7}{|c|}{} \\
\hline $\mathbf{3 0}$ & 41.4 & 19.8 & 39.6 & 17.9 & 40.7 & 19.1 \\
\hline $\mathbf{6 0}$ & 37.6 & 17.3 & 35.3 & 14.8 & 35.7 & 15.8 \\
\hline $\mathbf{9 0}$ & 29.1 & 13.7 & 27.5 & 11.6 & 28.2 & 12.7 \\
\hline Mean & $\mathbf{3 6 . 0}$ & $\mathbf{1 6 . 9}$ & $\mathbf{3 4 . 1}$ & $\mathbf{1 4 . 8}$ & $\mathbf{3 4 . 9}$ & $\mathbf{1 5 . 9}$ \\
\hline
\end{tabular}

\section{Relative humidity (RH \%)}

Blue plastic house had lower $\mathrm{RH}$ by 1.5 in maximum $\mathrm{RH} \%$ and more 2 in minimum $\mathrm{RH} \%$ compared to the control. On the other hand, the red treatment had the highest $\mathrm{RH} \%$, where it increased by 1 in maximum and 2 in minimum than $\mathrm{RH} \%$ in the control treatment (Table 3). These results could be attributed to the effect of plastic net colour on the increasing of maximum and minimum temperature in 
different type of covering material. Humidity is strongly influenced by outside humidity and temperature. RH \% increases under the plastic houses, not only because of the plastic cover but also due to vegetative mass of the grown plant in the house (AbouHadid et. al.., 1988).

Data presented showed that the maximum and minimum $\mathrm{RH}$ were between 25 - $95 \%$ under the control plastic house throughout the season, while maximum and minimum RH decreased especially during March and April, which was less than $20 \%$ in minimum under all treatments, however the maximum $\mathrm{RH}$ ranged between $80-$ $90 \%$.

Normal plant growth generally occurs at relative humidity between $25-80 \%$. A secondary effect of relative humidity is the response of pathogenic organisms. For example most pathogenic spores will not germinate at relative humidity below $95 \%$ (Aldrich and Bartok, 1989).

Table 3. Average of maximum and minimum RH \% under different plastic net colour treatments during the two growing seasons of 2009 and 2010.

\begin{tabular}{|c|c|c|c|c|c|c|}
\hline \multirow{3}{*}{$\begin{array}{c}\text { Days after } \\
\text { transplanting }\end{array}$} & \multicolumn{6}{|c|}{ Net colours } \\
\hline & \multicolumn{2}{|c|}{ Red } & \multicolumn{2}{|c|}{ Blue } & \multicolumn{2}{|c|}{ Control } \\
\hline & Max. & Min. & Max. & Min. & Max. & Min. \\
\hline \multicolumn{7}{|c|}{ First season } \\
\hline 30 & 91.9 & 30.4 & 90.6 & 22.5 & 90.0 & 27.7 \\
\hline 60 & 91.3 & 33.5 & 88.5 & 30.8 & 89.5 & 32.8 \\
\hline 90 & 90.7 & 41.6 & 88.7 & 39.7 & 88.7 & 40.4 \\
\hline Mean & 91.3 & 35.2 & 89.3 & 31.0 & 89.4 & 33.6 \\
\hline \multicolumn{7}{|c|}{ Second season } \\
\hline 30 & 92.8 & 34.7 & 90.5 & 23.7 & 91.0 & 28.0 \\
\hline 60 & 92.3 & 38.8 & 89.4 & 31.2 & 90.4 & 33.2 \\
\hline 90 & 91.6 & 47.1 & 88.7 & 38.2 & 89.6 & 40.8 \\
\hline Mean & 92.2 & 40.2 & 89.5 & 31.0 & 90.3 & 34.0 \\
\hline
\end{tabular}

\section{Soil temperature}

Data presented in Table 4 showed that average soil temperature influenced by air temperature under the different types of plastic houses and that average soil temperature varied according to the type of plastic colour. Average soil temperature (Table 4) shows that the red treatment has the highest value followed by the control and blue treatments. The soil temperature decreased under blue net cover by $0.9^{\circ} \mathrm{C}$, while soil temperature increased by $1.4{ }^{\circ} \mathrm{C}$ under red net cover. Data indicated the same trend during the two experimental seasons. These results are in a harmony with 
that obtained by Abou-Hadid et. al.., (1988) who found that there was a positive correlation between air temperature under plastic house and soil temperature. These results agreed with Mansito and Caballero, (1986), who reported that soil temperature was affected by radiation intercepted by plastic cover.

Table 4. Average of soil temperature under different plastic net colour treatments during the two growing seasons of 2009 and 2010.

\begin{tabular}{|c|c|c|c|c|}
\hline \multirow{2}{*}{ Plastic Mulch } & \multicolumn{3}{|c|}{ Net colours } & \multirow{2}{*}{ Mean } \\
\cline { 2 - 5 } & Black & Transparence & Without & \\
\hline \multicolumn{5}{|c|}{ First season } \\
\hline Red & 28.0 & 29.0 & 27.0 & $\mathbf{2 8 . 0}$ \\
\hline Blue & 27.0 & 28.0 & 26.0 & $\mathbf{2 7 . 0}$ \\
\hline Control & 29.0 & 30.0 & 28.0 & $\mathbf{2 9 . 0}$ \\
\hline Mean & $\mathbf{2 8 . 0}$ & $\mathbf{2 9 . 0}$ & $\mathbf{2 7 . 0}$ & \\
\hline Red & & Second season & 27.0 & $\mathbf{2 8 . 7}$ \\
\hline Blue & 30.0 & 29.0 & 26.0 & $\mathbf{2 7 . 3}$ \\
\hline Control & 28.0 & 28.0 & 28.0 & $\mathbf{2 9 . 3}$ \\
\hline Mean & 30.0 & 30.0 & $\mathbf{2 7 . 0}$ & \\
\hline
\end{tabular}

\section{Plant growth parameters}

\section{Plant height (cm)}

Concerning the data of plant height, data revealed that, there were significant differences between treatments during the two experimental seasons of 2009 and 2010 (Table 5). Plastic net house covers affected plant height significantly, where white net cover gave the highest value of plant height, followed by red and blue, with a significant difference among them during the two experimental seasons. Also, plant height under transparent mulch treatment was significantly higher than black and without mulch treatments during both seasons.

Data showed also that the highest plant height was recorded by the plants under the white plastic net house and transparent mulch treatment, while the lowest plant height was recorded by the plants under blue net cover and without mulch. These results are in agreement with those stated by Fjeld et. al.., (1993), who indicated that red light significantly reduced plant height compared with white light whereas blue light significantly increased plant height. 
Table 5. Plant height $(\mathrm{cm})$ under different plastic net colour treatments during the two growing seasons of 2009 and 2010.

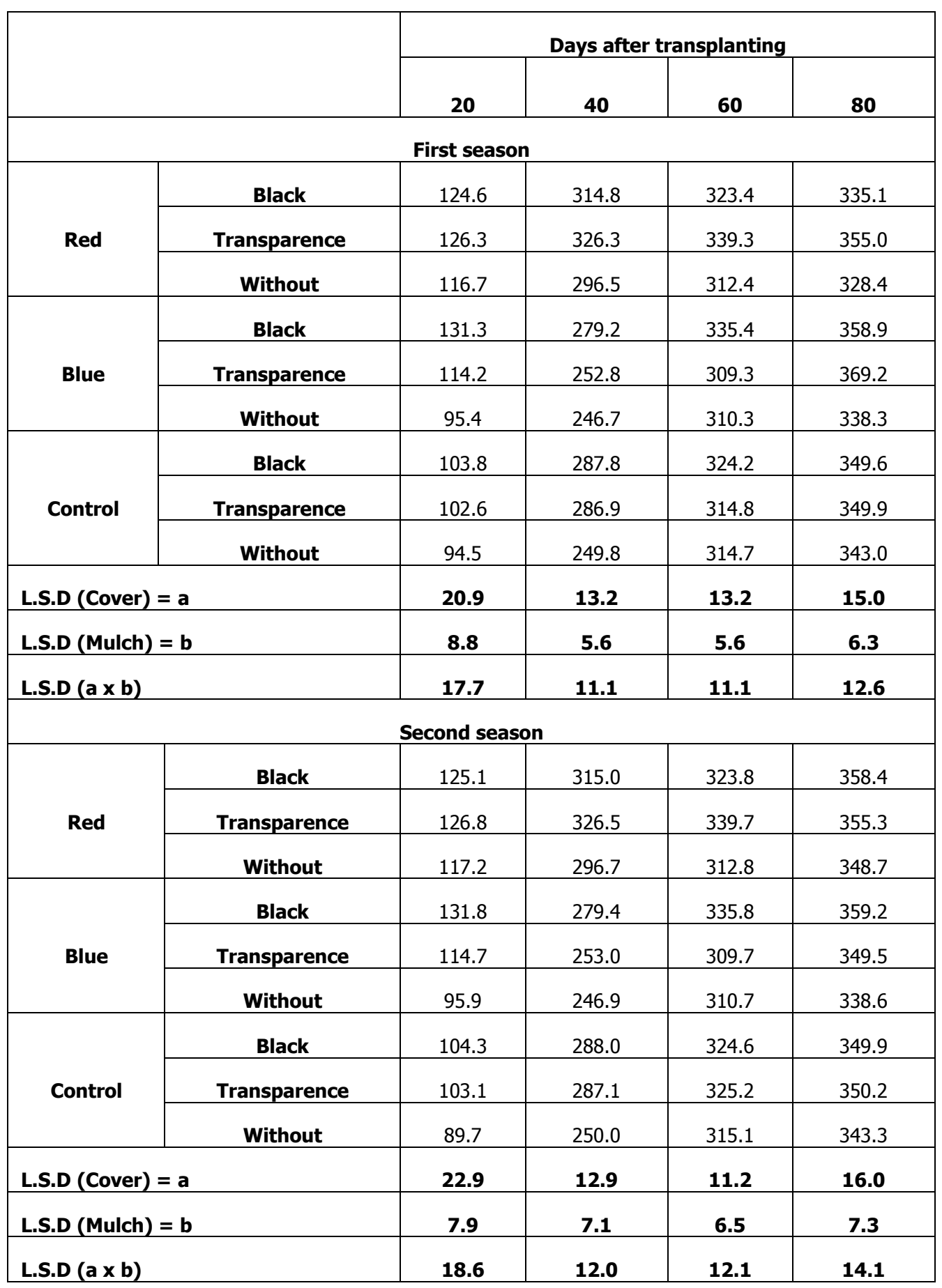

\section{Number of leaves per plant}

The influence of different plastic net house covers and soil mulch on number of leaves of cucumber plant is presented in Table 6. Different plastic net house covers have significant effect on number of leaves per plant. The highest number of leaves was recorded under red net cover, while the lowest number of leaves occurred under blue net cover treatment. This trend was observed during the two seasons. Data 
showed that, number of leaves of plants without mulch was significantly lower than transparent and black mulch treatments in all records obtained throughout both growing seasons. Regarding the interaction between plastic net house covers and soil mulch, data showed that plant grown under the white net cover combined with transparent mulch gave the highest number of leaves per plant, while the lowest number of leaves was recorded by the blue net cover combined without soil mulch.

Table 6. Number of leaves per plant under different plastic net colour treatments during the two growing seasons of 2009 and 2010.

\begin{tabular}{|c|c|c|c|c|c|}
\hline & & \multicolumn{4}{|c|}{ Days after transplanting } \\
\hline & & 20 & 40 & 60 & 80 \\
\hline \multicolumn{6}{|c|}{ First season } \\
\hline \multirow{3}{*}{ Red } & Black & 14.8 & 28.5 & 33.3 & 37.0 \\
\hline & Transparence & 15.9 & 29.2 & 34.4 & 39.3 \\
\hline & Without & 13.8 & 27.6 & 31.4 & 36.5 \\
\hline \multirow{3}{*}{ Blue } & Black & 15.6 & 29.8 & 32.8 & 34.9 \\
\hline & Transparence & 16.3 & 31.2 & 35.0 & 38.0 \\
\hline & Without & 13.8 & 27.3 & 30.7 & 33.7 \\
\hline \multirow{3}{*}{ Control } & Black & 13.0 & 28.8 & 31.3 & 34.3 \\
\hline & Transparence & 14.5 & 29.9 & 33.5 & 37.8 \\
\hline & Without & 12.8 & 27.9 & 30.9 & 32.4 \\
\hline \multicolumn{2}{|c|}{ L.S.D (Cover) = a } & 1.9 & 1.4 & 1.7 & 1.5 \\
\hline \multicolumn{2}{|c|}{ L.S.D (Mulch) = b } & 0.8 & 0.6 & 0.7 & 0.6 \\
\hline \multicolumn{2}{|c|}{ L.S.D (a x b) } & 1.6 & 1.2 & 1.4 & 1.3 \\
\hline \multicolumn{6}{|c|}{ Second season } \\
\hline \multirow{3}{*}{ Red } & Black & 14.1 & 28.2 & 31.6 & 37.2 \\
\hline & Transparence & 15.2 & 30.1 & 34.7 & 39.5 \\
\hline & Without & 13.9 & 26.8 & 29.7 & 35.7 \\
\hline \multirow{3}{*}{ Blue } & Black & 13.9 & 27.8 & 32.1 & 36.1 \\
\hline & Transparence & 14.6 & 29.2 & 35.3 & 38.2 \\
\hline & Without & 12.1 & 26.8 & 29.0 & 34.9 \\
\hline \multirow{3}{*}{ Control } & Black & 15.7 & 29.2 & 32.6 & 36.5 \\
\hline & Transparence & 16.2 & 30.3 & 33.8 & 38.0 \\
\hline & Without & 14.1 & 27.4 & 30.2 & 35.6 \\
\hline \multicolumn{2}{|c|}{ L.S.D (Cover) = a } & 1.7 & 1.2 & 1.5 & 1.5 \\
\hline \multicolumn{2}{|c|}{ L.S.D (Mulch) = b } & 0.9 & 0.7 & 0.6 & 0.8 \\
\hline \multicolumn{2}{|c|}{ L.S.D (a x b) } & 1.5 & 1.3 & 1.3 & 1.1 \\
\hline
\end{tabular}




\section{Stem diameter $(\mathrm{mm})$}

The statistical analyses show that the treatments had significant effects on cucumber plant stem diameter during the two growing seasons (Table 7). The stem diameter value was found under red net cover, followed by white net treatment, while the lowest stem diameter value obtained with blue net cover treatment. The effect of soil mulch on stem diameter indicated that the highest stem diameter value was obtained under transparent mulch treatment, followed by black mulch, while the lowest stem diameter value was occurred without using mulch treatment.

Table 7. Stem diameter $(\mathrm{mm})$ under different plastic net colour treatments during the two growing seasons of 2009 and 2010.

\begin{tabular}{|c|c|c|c|c|c|}
\hline & & \multicolumn{4}{|c|}{ Days after transplanting } \\
\hline & & 20 & 40 & 60 & 80 \\
\hline \multicolumn{6}{|c|}{ First season } \\
\hline \multirow{3}{*}{ Red } & Black & 3.2 & 4.1 & 5.8 & 6.5 \\
\hline & Transparence & 3.4 & 4.4 & 6.1 & 6.8 \\
\hline & Without & 3.0 & 3.9 & 5.6 & 6.2 \\
\hline \multirow{3}{*}{ Blue } & Black & 2.9 & 4.0 & 4.8 & 5.7 \\
\hline & Transparence & 3.0 & 4.2 & 4.9 & 6.1 \\
\hline & Without & 2.7 & 3.9 & 4.6 & 5.3 \\
\hline \multirow{3}{*}{ Control } & Black & 3.1 & 4.0 & 5.0 & 6.2 \\
\hline & Transparence & 3.5 & 4.5 & 5.2 & 6.6 \\
\hline & Without & 2.8 & 3.7 & 4.5 & 6.0 \\
\hline \multicolumn{2}{|c|}{ L.S.D (Cover) = a } & 0.2 & 0.3 & 0.2 & 0.4 \\
\hline \multicolumn{2}{|c|}{ L.S.D (Mulch) = b } & 0.1 & 0.1 & 0.1 & 0.2 \\
\hline \multicolumn{2}{|c|}{ L.S.D (a x b) } & 0.2 & 0.3 & 0.2 & 0.4 \\
\hline \multicolumn{6}{|c|}{ Second season } \\
\hline \multirow{3}{*}{ Red } & Black & 3.4 & 4.6 & 6.0 & 6.6 \\
\hline & Transparence & 3.6 & 4.7 & 6.5 & 6.8 \\
\hline & Without & 3.1 & 4.5 & 5.8 & 6.1 \\
\hline \multirow{3}{*}{ Blue } & Black & 3.0 & 4.3 & 5.0 & 6.0 \\
\hline & Transparence & 3.3 & 4.5 & 5.5 & 6.4 \\
\hline & Without & 2.9 & 4.2 & 4.7 & 5.7 \\
\hline \multirow{3}{*}{ Control } & Black & 3.6 & 4.4 & 5.3 & 6.4 \\
\hline & Transparence & 3.7 & 4.8 & 5.7 & 6.6 \\
\hline & Without & 3.0 & 4.2 & 5.1 & 6.0 \\
\hline \multicolumn{2}{|c|}{ L.S.D (Cover) = a } & 0.2 & 0.3 & 0.2 & 0.4 \\
\hline \multicolumn{2}{|c|}{ L.S.D $($ Mulch) = b } & 0.1 & 0.1 & 0.1 & 0.2 \\
\hline \multicolumn{2}{|c|}{ L.S.D (a x b) } & 0.2 & 0.3 & 0.2 & 0.4 \\
\hline
\end{tabular}

\section{Total leaf area $\left(\mathrm{cm}^{2}\right)$}

The red net plastic colour recorded the highest leaf area followed by white (control) and blue colour; respectively; while transparence plastic mulching treatment 
recorded the highest leaf area followed by without and with black treatments; respectively (Table 8). Interaction between net plastic colours and mulching colour showed that the transparence mulching under red net colour has the highest value of leaf area, while the black plastic mulching under blue net recorded the lowest value of leaf area in the first and the second seasons. These results are in conformity with the findings of Bhella and Kwoleck (1984) who found significant increases in plant growth were observed under polyethylene mulch compared to the treatment without mulching.

The faster rates of growth under the mulch could be due to the increase on soil temperature, which could have handed physiological changes in the transplants. The improved temperature under mulch might be stimulated root growth early in the season. This coupled with increased efficiency of nutrient uptake per unit root could have been involved in the mulch induced shoot growth and increased the leaf biomass (Farag et. al.., 2010). The obtained results are in agreement also with those of Soltani et. al.., (1995), who revealed that mulching has contributed positively to higher soil production, temperature and consequently improving growth and yield.

Table 8. Total leaf area per plant $(\mathrm{cm} 2)$ under different plastic net colour treatments after 80 days, during the two growing seasons of 2009 and 2010.

\begin{tabular}{|c|c|c|c|c|}
\hline & Black & Transparence & Without & Mean \\
\hline \multicolumn{5}{|c|}{ First season } \\
\hline Red & 6427.7 & 6513.7 & 6394.7 & 6445.4 \\
\hline Blue & 4352.3 & 5278.0 & 4410.3 & 4680.2 \\
\hline Control & 5648.6 & 5590.0 & 5337.3 & 5525.3 \\
\hline Mean & 5476.2 & 5793.9 & 5380.8 & \\
\hline \multicolumn{5}{|c|}{ Second season } \\
\hline Red & 5855.5 & 6030.4 & 5754.8 & 5880.2 \\
\hline Blue & 5536.4 & 5580.5 & 5492.6 & 5536.5 \\
\hline Control & 5732.1 & 5750.2 & 5554.4 & 5678.9 \\
\hline Mean & 5708.0 & 5787.0 & 5600.6 & \\
\hline L.S.D & $($ Cover $)=a$ & \multicolumn{2}{|c|}{ (Mulch) $=\mathbf{b}$} & (axb) \\
\hline First season & 252.6 & \multicolumn{2}{|c|}{106.6} & 213.1 \\
\hline Second season & 260.7 & \multicolumn{2}{|c|}{120.7} & 232.2 \\
\hline
\end{tabular}

\section{Total fruit weight (g)}

Cumulative yields of cucumber fruits under different plastic covers are shown in Table 9. The results showed significant differences between net colour and mulching colour on total yield per plant in both season. The control plastic net colour 
(white net) has the highest yield followed by the red and the blue treatments; while transparence plastic mulching treatment was recorded the highest yield followed by black and without mulching treatments, respectively.

Interaction between plastic net colours and mulching colour indicated that the transparence mulching under white net had the highest value of yield; while without mulching under blue net was given the lowest yield.

Increased yield could be largely attributed to the increase in soil temperature due to application of mulch, which resulted in enhancement of soil environment around roots of cucumber plants, which led to increase plant growth and hence increase nutrient absorption and uptake. These results were in line with those obtained by (Salman et. al.., 1991). Blue colour of polyethylene sheets reduced the yield of almost all vegetables in greenhouse, and blue colour had the worse effect. The low yield probably occurs under low radiation levels (Dayan et. al.., 1986). There were some indications that a large change in total solar radiation (under different colours plastic sheets) induced a change in proportional dry matter distribution to the fruits. These results are supported by those stated by (Abdrabbo et. al.., 2009), who reported that increased yield could be largely attributed to appropriate environmental conditions (light intensity - air temperature - soil temperature - air humidity) due to application of the white net cover, which resulted in enhancement of soil condition around roots zone of cucumber, and increase plant growth and hence increasing nutrient absorption and uptake

Table 9. Total fruit weight ( $\mathrm{g} / \mathrm{plant})$ under different plastic net colour treatments during the two growing seasons of 2009 and 2010.

\begin{tabular}{|c|c|c|c|c|}
\hline & Black & Transparence & Without & Mean \\
\hline \multicolumn{5}{|c|}{ First season } \\
\hline Red & 1103.0 & 1315.8 & 1145.2 & 1188.0 \\
\hline Blue & 1008.4 & 1231.8 & 930.8 & 1057.0 \\
\hline Control & 1199.0 & 1444.3 & 1132.3 & 1258.5 \\
\hline Mean & 1103.5 & 1330.6 & 1069.4 & \\
\hline \multicolumn{5}{|c|}{ Second season } \\
\hline Red & 1209.4 & 1330.2 & 1134.5 & 1224.7 \\
\hline Blue & 1022.6 & 1290.7 & 1098.3 & 1137.2 \\
\hline Control & 1349.2 & 1420.8 & 1121.4 & 1297.1 \\
\hline Mean & 1193.7 & 1347.2 & 1118.1 & \\
\hline L.S.D & (Cover) $=\mathrm{a}$ & \multicolumn{2}{|c|}{ (Mulch) $=\mathbf{b}$} & (axb) \\
\hline First season & 39.7 & \multicolumn{2}{|c|}{16.8} & 33.5 \\
\hline Second season & 41.9 & \multicolumn{2}{|c|}{18.6} & 36.7 \\
\hline
\end{tabular}




\section{REFERENCES}

1. Abdrabbo, M. A. A., A. A. Farag and M. K. Hassanein. 2009. Irrigation requirements for cucumber under different mulch colours. Egypt. J. Hort., 36: $333-346$

2. Abou-Hadid, A. F., A. S. El-Beltagy and H. M. El-Saeid. 1988. Potential evapotranspiration for different regions and water consumptive use patterns under plastic house conditions in Egypt. Egypt, J. Hort. 15.

3. Aldrich, R. A. and J. W. Bartok. 1989. Greenhouse Engineering. Northeast regional agricultural engineering service. 33: 61 - 71.

4. Bhella, H. S. and W. F. Kwolek. 1984. The effects of trickle irrigation and plastic mulch on 'Zucchin'. Hort. Sci., 19: 410 - 411.

5. Cockshull, K. E. 1988. The integration of plant physiology with physical changes in the greenhouse climate. Acta Hort. 229: 113-123.

6. Dayan, E., H. Z. Enoch, M. Fuchs and I. Zipori. 1986. Suitability of greenhouse building types and roof cover materials for growth of export tomatoes in the Besor region of Israel. II. Effect on fresh and dry matter production. Biotronics. 15: 71 -7 9.( C.F. Hanan, J.J. 1990. The influence of Greenhouses on Internal climate with special reference to Mediterranean regions. Acta Hort. 287: 23 - 34.)

7. El-Aidy, F. 1990. The effect of planting date, density, variety and shade on production of cucumber under tunnels. Acta Hort., 287: 281 - 287.

8. Farag, A. A., M. A. A. Abdrabbo and M. K. Hassanein. 2010. Response of cucumber for mulch colours and phosphorus levels grown under greenhouse. Egypt. J. Hort., 37: 53 - 64.

9. Fjeld, T., M. Rudnicki and R. Moe. 1993. Effects of light quality on flower and bud development in Begonia X hiemalis Fotsch. Gartenbauwissenschaft. 58: 154 157.

10. Halil, K. and M. N. Demirtas. 2006. Effects of different irrigation regimes and mulches on yield and macronutrition levels of drip-irrigated cucumber under open field conditions. J. Plant Nutr., 29: 1675 - 1690.

11. Hanan, J. J. 1990. The influence of greenhouses on internal climate with special reference to mediterranean regions.Acta Hort, 287: 23 - 33.

12. Hanras, M. 1970. Amelioration dans la qualité des films polyethylene. 4 éme Col. Inter.Col. "Plastics in agriculture", 255 - 263.

13. Lippert, T. L. H. and F. L. Witing. 1964. Soil moisture bands of petroleum and polyethylene mulches. Proc. Amer. Soc. Hort. Sci. 85: 541 - 546. 
14. Mansito, P. and M. Caballero. 1986. Temperature patterns in greenhouses covered with several types of plastic films in Canary Islands. Acta Horticulturae. 246:75 - 78.

15. Medany, M. A., A. F. Abou-Hadid, M. H. Khalifa and A.S. El-Beltagy. 1991. Studies on the heat requirements of sweet pepper plant grown plastic houses in Egypt. Acta. Hort., (287): 255 - 260.

16. Mortensen, L. M. and E. Stromme. 1987. Effect of light quality on some greenhouse crops. Sci. Hortic. 33: 27 - 36.

17. Salman, H. M. and S. F. Gorski. 1985. The effect of clear and black polyethylene mulches on the soil environment. Res. Circular, Ohio Agric. Res. And Development Center, 288: 7 - 9.

18. Salman, S. R., A. F. Abou-Hadid, M. O. Bakry and A. S. El-Beltagy. 1991. The effect of plastic mulch on the microclimate of plastic house. Acta Hort., 287: 417 $-425$.

19. Soltani, N., J. L. Anderson and A. R. Hamson. 1995. Growth and analyses of watermelon plants with mulches and row covers. J. Amer. Soc. Hort. Sci., 120: 1001 - 1009.

20. Steel, R. G. D. and J. H. Torrie. 1980. Principle and procedures at statistices, a biometrical approach. $2^{\text {nd }}$ Ed. Mc Grow- Hill Book Company. 


\section{تأثير لون غطاء الصوب الثبكية ويلاستيك غطاء التربة على نمو وإنتاجية الخيار}

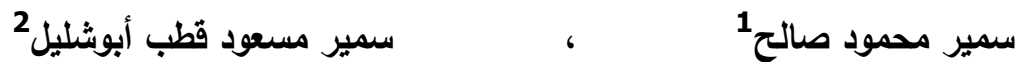

$$
\begin{aligned}
& \text { 1. الدعطل المركزي للمناخ الزراعي- مركز البحوث الزراعية - وزارة الزراعة- دقي - جيزة. } \\
& \text { 2. قسم البيئة والزراعة الحيوية - كلية الزراعة بالقاهرة - جامعة الأزهر. }
\end{aligned}
$$

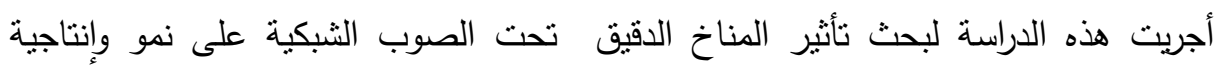

الخيار المنزرع خلال العروة الخريفي موسمي 2009، 2010 فى منطقة النوبارية - محافظة البحيرة. حيث تم دراسة التأثيرات الناتجة عن ألوان شبك البلاستيك الأحمر، والأزرق، والكنترول (أبيض)

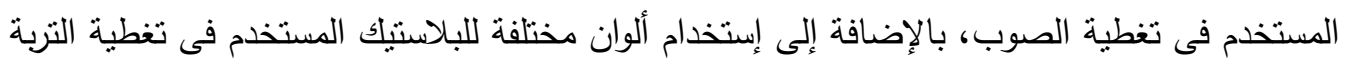
(الملش) حيث تم إستخدام لونين هما الأسود، والثفاف، مقارنة بالكنترول (بدون تغطية).

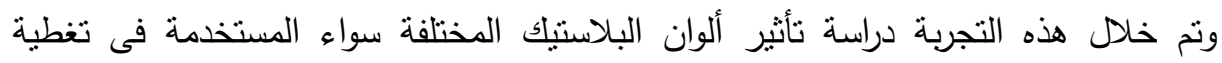

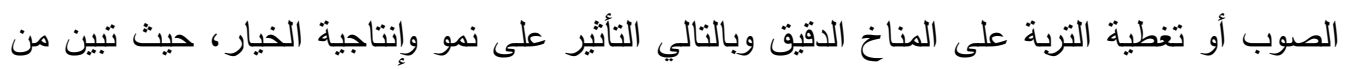

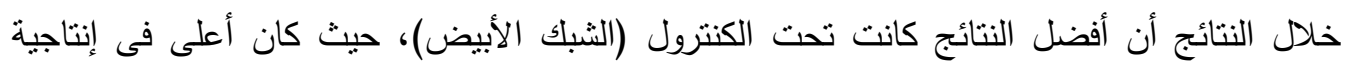

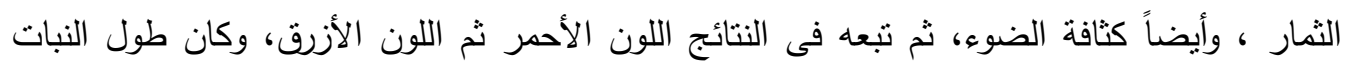

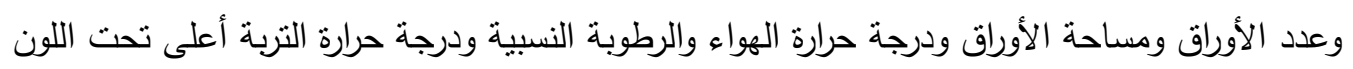

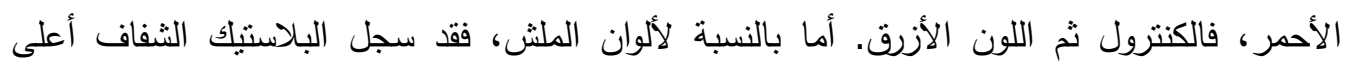

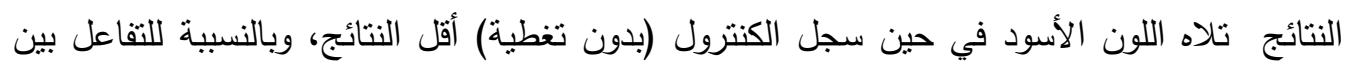

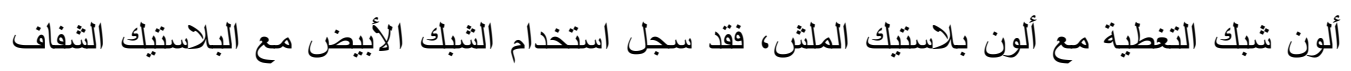

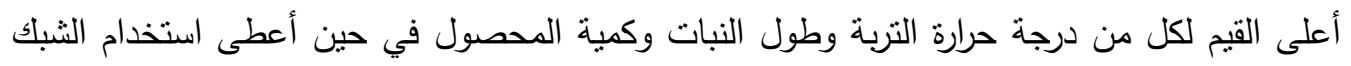
الأحمر مع البلاستيك الثفاف أعلى القيم لكل من عدد الأوراق ومساحة سطح الأوراق وكذا قطر 